\title{
KRT8 wt Allele
}

National Cancer Institute

\section{Source}

National Cancer Institute. KRT8 wt Allele. NCI Thesaurus. Code C126963.

Human KRT 8 wild-type allele is located in the vicinity of $12 q 13$ and is approximately $53 \mathrm{~kb}$ in length. This allele, which encodes keratin, type II cytoskeletal 8 protein, plays a role in the structure of striated muscle and simple epithelia. Mutation of the gene is associated with cryptogenic cirrhosis. 